\author{
L. Pisnia ${ }^{1}$, I. Cherniavskiy ${ }^{2}$, S. Petrukhin ${ }^{2}$, E. Serikova ${ }^{3}$ \\ ${ }^{1}$ Ukrainian Scientific Research Institute of Ecological Problems, Kharkiv, Ukraine \\ ${ }^{2}$ Military Institute of Tank Forces of National Technical University "KhPI", Kharkiv, Ukraine \\ ${ }^{3}$ A.M. Pidhorny Institute for Mechanical Engineering Problems NAS of Ukraine, Kharkiv, Ukraine
}

\title{
EXPERT-ANALYTICAL FORECASTING OF NUCLEAR DAMAGE FOCI ON THE MONITORING ISSUES OF MILITARY CHARACTER EMERGENCY SITUATIONS
}

\begin{abstract}
Relevance. The problem of complex assessment of possible boundaries of nuclear damage in military character emergency situations is considered. The aim of the work is to determine the "necessary and sufficient" parameters of a nuclear explosion and to assess their contribution to identification problems of nuclear foci, identify their features and boundaries, assess the doses of gamma-neutron exposure of the population, and effectively distribute forces and facilities for actions in nuclear foci. Method. In order to correctly assess the situation in the nuclear foci and plan the necessary measures, it was evaluated the contribution of the output "necessary and sufficient" parameters for detecting a nuclear explosion of different power, shape and type of ammunition according to the measurability criteria using the hierarchy analysis method of T. Saati adapted for the problems under consideration. The advantage of using the hierarchy analysis method for complex assessment of possible nuclear foci in military character emergency situations is the possibility of finding the weight coefficients of each element of a complex hierarchical system, taking into account their interrelationships and mutual influence through pairwise expert comparisons. The received weights (priorities) on levels of hierarchy allow to define the contribution of elements of the bottom level on achievement of the purpose which is formulated on the top level. The process of assessing boundaries of nuclear damage is proposed in the form of three tasks according to the criteria: type of nuclear explosion, TNT equivalent and type of ammunition, which represent a complex expert-analytical assessment of the damaging factors of a nuclear explosion. Results. The paper presents the results of expert-analytical assessment of possible boundaries of nuclear damage in emergency situations of a military nature in the context of uncertainty of the initial information in the detection of nuclear explosions. Conclusions. The need to take into account the spectrum of neutron radiation in the prediction of nuclear foci is confirmed as "sufficient" information with the aim of making adequate and effective predictions of nuclear foci. It is determined that when assessing nuclear foci, both on the basis of the type of nuclear explosion, its power, and the shape of nuclear munition, it is better to predict and manifest (identify) the source of radiation-mechanical damage. When a combined radiation damage and radiation damage is detected in a "pure" form, the best criterion is based on the type of nuclear munition.
\end{abstract}

Keywords: boundaries of nuclear damage; the damaging factors of a nuclear explosion; hierarchy analysis method; an expert-analytical assessment.

\section{ABBREVIATIONS}

$B N D$ boundaries of nuclear damage;

$N E$ nuclear explosion;

$R M D$ radiation-mechanical damage;

$R T D$ radiation-thermal damage;

$C R D$ combined radiation damage;

$R D$ radiation damage;

$N A$ nuclear ammunition;

MHA method of hierarchical analysis;

$D F$ damaging factors;

CV criterion for the variability;

$T N E$ type of nuclear explosion;

TNA type of nuclear ammunition;

$T E$ trotyl equivalent.

\section{NOMENCLATURE}

$q \quad$ nuclear explosion power in TNT equivalent;

$H$ height of the explosion.

\section{Introduction}

In the conditions of increasing danger of the nuclear weapons use, in emergency situations of a military nature [1-5], the questions of prompt and reliable current situation assessment, the identification of features and boundaries of nuclear damage (BND) remain relevant [6-8]. In the literature, depending on the dominance of this or that detrimental factors of a nuclear explosion (NE), foci can be defined: with predominantly radiation-mechanical damage (RMD); radiation-thermal damage (RTD); with combined radiation damage $(\mathrm{CRD})$; with radiation damage $(\mathrm{RD})$ in a «pure» form [9-13]. The last two boundaries are typical for tactical nuclear ammunitions (NA) - small and ultra-small-capacity ammunition, as well as neutron munitions, identification and assessment of the situation after application of which causes significant difficulties.

\section{Problem statement}

Uncertainty in the identification and assessment of the situation through forecasting is largely due to the information lack on the NE parameters. Existing methods use the trotyl equivalent $q$, kt of the NA, which determines the power of the NE, as well as the coordinates of the NE point, including the explosion height of the monition $H, \mathrm{~m}$. These parameters are sufficient to classify the NE type, but not in all cases it is «necessary and sufficient» to characterize the nuclear damage parameters $[14,15]$. The additional information presence on the spectral composition of the neutron radiation of penetrating radiation $\mathrm{NE}$ is reasonable to consider sufficient for the correct assessment of the specifics of possible damage and further consequences forecasting in the current situation.

\section{Review of literature}

It was shown earlier [6, 7] that the information lack on the spectral composition of the NE penetrating radiation determining the NA type at specified distances from the epicenter leads to unacceptable errors in estimating the doses of gamma-neutron exposure of the 
population, and as a result leads to inefficient distribution forces and means for actions in the BND.

Thus, there arises a hypothesis that the generalized multicriterial BND estimation should be carried out in the NE type, in the power of NE and in the NA type. Therefore, as the necessary information, it is expedient to consider the altitude or coordinates of the NE, the trotyl equivalent of the NA, and to consider as sufficient additional information of NE neutron radiation spectrum. To what extent the neutron radiation spectrum could be considered as «sufficient» information for qualitative BND assessment is the currently open question. To test this assumption, it is necessary to construct hierarchical structures of expert-analytical forecasting of the situations development in the presence of this necessary and sufficient initial information.

The attempt to evaluate the contribution of the socalled «necessary and sufficient» BND parameters by applying the T. Saati hierarchical analysis method (MHA) has been provided [16,17]. The method adapted for the issues under consideration in terms of the modified verbal interpretation of the scale values of pair wise comparisons [18]. The aim is to specify the "necessary and sufficient" parameters of nuclear explosion and to assess their contribution to identification tasks of nuclear damage foci, to identify their features and boundaries, to assess the gamma-neutron exposure doses of the population, and effectively distribute forces and facilities for actions in nuclear foci.

\section{Materials and methods}

The essence of the MHA implementation is follow. Firstly, for the decomposition of the tasks stages of estimating the BND in the form of hierarchy subcriteria consisting, criteria, factors and alternatives to the consequences with the displayed links between the individual elements. Secondly, for construction of matrices of elements paired comparisons on the basis of expert judgments. Thirdly, for calculating the priorities and importance of the elements, with further expert judgments processing, the results of which determine the generalized weighted relative degree of interaction or interdependence of hierarchy all elements, which is expressed in a standardized numerical form in the form of global priorities. With such treatment, the analytical approach of constructing the events tree and consequences with expert procedures of pairwise comparisons of the elements importance is combined, using algebraic matrix theory, and allows to consider the situation integrally «from top to bottom» and «from bottom to top», while including all available elements data, and to evaluate their weight contributions to the decision, that is, to find solutions in conditions of multicriterion.

Pairwise comparisons were carried out on the unified scale (Table 1) of pairwise expert evaluation (weighing) obtained on the basis of the «T. Saati scale» formulation.

Table 1. The unified scale of pairwise expert evaluation

\begin{tabular}{|c|c|c|}
\hline $\begin{array}{l}\text { T. Saati's } \\
\text { score }\end{array}$ & $\begin{array}{l}\text { Verbal-argumentative } \\
\text { evaluation(weight) }\end{array}$ & $\begin{array}{c}\text { Note } \\
\text { (comments) }\end{array}$ \\
\hline 0 & $\begin{array}{l}\text { Criteria are incomparable in terms of } \\
\text { achieving the goal }\end{array}$ & The absence of mutual connection and influence \\
\hline 1 & $\begin{array}{l}\text { Criteria are equivalent in terms of } \\
\text { achieving the goal }\end{array}$ & Objects are comparable and / or interrelated. No preference data \\
\hline 2 & $\begin{array}{l}\text { Weak preference of one in comparison } \\
\text { with another one }\end{array}$ & $\begin{array}{l}\text { It is qualitatively known about the preference of one in comparison with } \\
\text { another, but the number of reliable and reliable data on preferences is } \\
\text { not enough to make a guaranteed decision about the preference }\end{array}$ \\
\hline 3 & $\begin{array}{l}\text { At least one of the factors indicates the } \\
\text { preference of one criterion over another }\end{array}$ & $\begin{array}{l}\text { At least one of the indicators (characteristics) of one is guaranteed } \\
\text { preferable to the other }\end{array}$ \\
\hline 4 & $\begin{array}{l}\text { The average preference of one criterion } \\
\text { over another }\end{array}$ & $\begin{array}{l}\text { More than one guaranteed indicator (criterion) confirms the preference } \\
\text { of one over the other, but less than half }\end{array}$ \\
\hline 5 & $\begin{array}{l}\text { The explicit preference of one over the } \\
\text { other one }\end{array}$ & $\begin{array}{l}\text { At least half of the indicators (criteria) are guaranteed to be preferable to one } \\
\text { in comparison with the other, with half of all data reliable and reliable from } \\
\text { the point of view of available statistics or at least probability }\end{array}$ \\
\hline 6 & $\begin{array}{l}\text { The average preference between «clear» } \\
\text { and «obvious» one over the other }\end{array}$ & $\begin{array}{l}\text { More than half of these indicators (criteria) confirm the preference of one } \\
\text { over the other (and half of the remaining can confirm the preference) }\end{array}$ \\
\hline 7 & $\begin{array}{l}\text { The obvious preference for one criterion } \\
\text { over another }\end{array}$ & $\begin{array}{l}\text { Domination of one over the other is obvious and practically confirmed } \\
\text { or does not cause doubts }\end{array}$ \\
\hline 8 & $\begin{array}{l}\text { More than an obvious preference, but not } \\
\text { yet absolute }\end{array}$ & $\begin{array}{l}\text { The preference of one over the other is not in doubt, but one can not } \\
\text { speak of absolute preference }\end{array}$ \\
\hline 9 & Absolute preference of one over the other & $\begin{array}{l}\text { The preference of one over the other is undeniable and is confirmed by } \\
\text { all the data, including the measurement error }\end{array}$ \\
\hline
\end{tabular}

\section{Experiments}

In view of the apparent complexity of the generalized expert-analytical assessment of the NE damaging factors (DF), that is, from the NA type, from the NE form and power, the paper presents three separate decompositions of these problems in the hierarchies form: based on the NE type (Fig. 1) based on the NE power classification (Fig. 2); based on the NA type (Fig. 3).

For the hierarchies description, we introduce the notation: $\mathrm{CV}$ - criterion for the variability of the NE parameters; TNE is the NE type; TNA is the NA type; $\mathrm{TE}$-trotyl equivalent (NE power). 


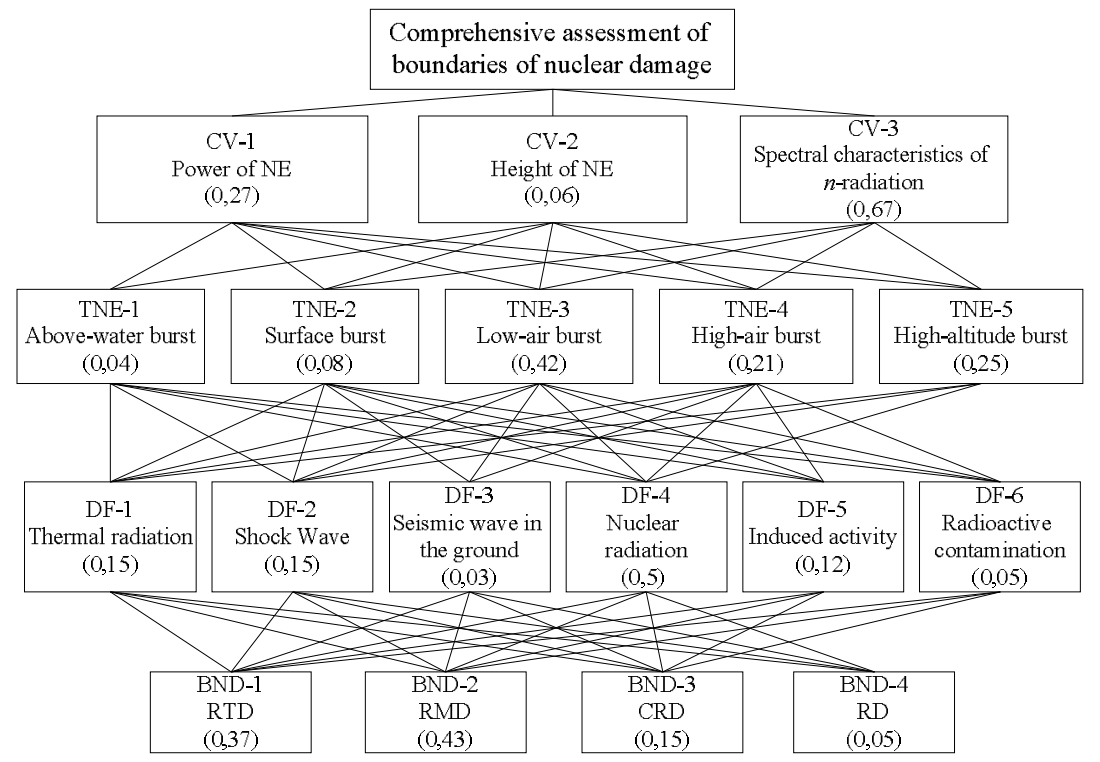

Fig. 1. Hierarchical task structure of the BND estimating with the criteria of the NE types (TNE-1-TNE-5) with the obtained values of the weight coefficients for all elements

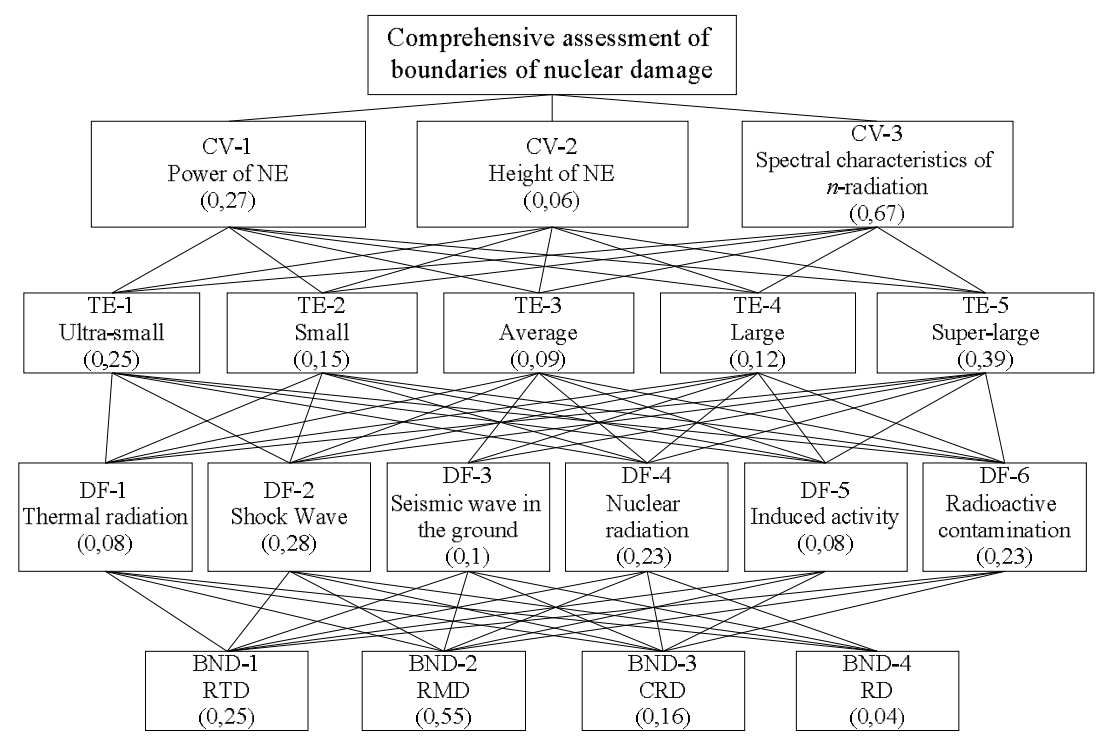

Fig. 2. Hierarchical structure of the BNF estimating task with the criteria of NE trotyl equivalent (TE-1-TE-5) with the obtained values of weight coefficients for all elements

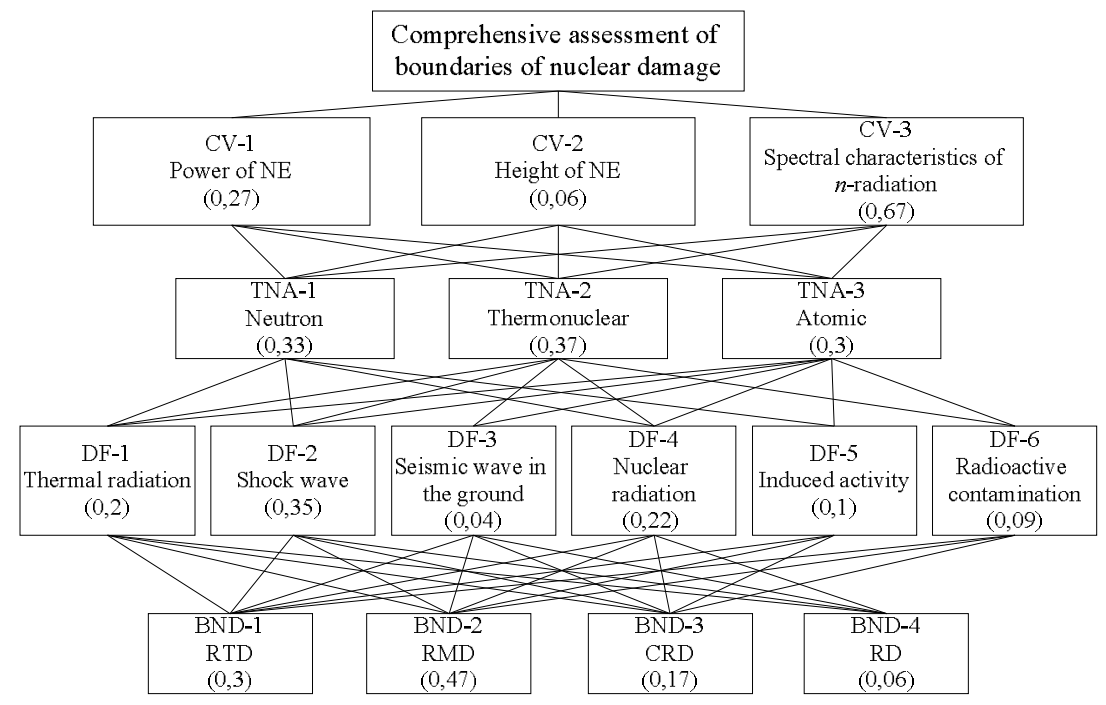

Fig. 3. Hierarchical structure of the BNF estimating task with the criteria of the ammunition NE type (TNA-1-TNA-3) with the obtained values of weight coefficients for all elements 
There is the goal at the first level of such hierarchy (Fig. 1-3): the comprehensive assessment BND. At the second level, the radiation monitoring system subcriteria are placed - the criteria for the environment state measuring (CV-1-CV-3), which, in fact, characterize the NE parameters: the power, the explosion height, and the spectral characteristics of neutron radiation, respectively. At the third level there are complex criteria in the form of NE classification:

- by the explosion type (Fig. 1) above-water burst (TNE-1); surface burst (TNE-2); low-air burst (TNE-3); high-air burst (TNE-4); high-altitude burst (TNE-5), reflecting the specifics of the DF formation in space;

- for the NE trotyl equivalent (Fig. 2), an ultrasmall (TE-1); small (TE-2); average (TE-3); large (TE4); super-large (TE-5), reflecting the boundaries of the destructive NE effect;

- by the NA type (Fig. 3) neutron (TNA-1); thermonuclear (TNA-2); Atomic (TNA-3), reflecting the priority of one or another of the DFaNE.

At the fourth level are the NE damaging factors: thermal radiation (DF-1); shock wave (DF-2); seismic wave in the ground (DF-3); nuclear radiation (DF-4); induced activity (DF-5); radioactive contamination (DF6), forming complex factors of impacts. At the fifth level, possible alternatives are presented - BND forecast: radiation-thermal damage (BND-1); radiationmechanical damage (BND-2); combined radiation damage (BND-3); radiation damage «in its pure form» (BND-4).

The important part of the the expert-analytical solution procedure is the formation of a table of questions assigned to experts for evaluating the elements in each of these hierarchies. The adequacy of the results often depends on the experts correct verbal motivation when constructing the matrices of pairwise comparisons, as an example, (Table 2), in which the serial number of the matrix level corresponds to the link presence with the top-level element.

In the paper, for the matrices judgments calculation, we used our own MHA priorities calculation program that takes into account the consistency and compatibility of the estimates, which are necessary conditions for the T. Saati MHA correct application.

Table 2.The formulation of the questions to be asked for the BND estimation based on the NE type

\begin{tabular}{|c|l|}
\hline $\begin{array}{c}\text { Hierarchy } \\
\text { level number }\end{array}$ & \multicolumn{1}{c|}{$\begin{array}{c}\text { Verbal motivation of experts in the construction } \\
\text { of matrices of pairwise congruences }\end{array}$} \\
\hline 2 & Which of the sub-criteria (measurability criteria) is preferable for determining the BND severity? \\
\hline 2.1 & $\begin{array}{l}\text { From the point of view of the NE power (the luminescence duration), what NE type will be decisive from } \\
\text { the point of view of the comprehensive BND assessment? }\end{array}$ \\
\hline 2.2 & From the point of view of the NE height, what NE type will be more likely to be determined? \\
\hline 2.3 & $\begin{array}{l}\text { From the point of view of determining the neutron radiation spectrum, which of the NE types will be } \\
\text { unambiguously characterized? }\end{array}$ \\
\hline 3.1 & Which of DF for the above-water burst (TNE-1) will be decisive or dominant? \\
\hline 3.2 & Which of DF for terrestrial surface burst (TNE-2) will be decisive or dominant? \\
\hline 3.3 & Which of DF for low-air burst (TNE-3) will be decisive or dominant? \\
\hline 3.4 & Which of DF for high-air burst (TNE-4) will be decisive or dominant? \\
\hline 3.5 & Which of DF for high-altitude burst (TNE-5) will be decisive or dominant? \\
\hline 4.1 & Which of BND will dominate the thermal radiation (DF-1)? \\
\hline 4.2 & Which of BND will dominate the shock wave DF-2? \\
\hline 4.3 & Which of BND will dominate the seismic wave in the ground (DF-3)? \\
\hline 4.4 & Which of BND will dominate the nuclear radiation (DF-4)? \\
\hline 4.5 & Which of BND will dominate the induced activity (DF-5)? \\
\hline 4.6 & Which of BND will dominate the radioactive contamination (DF-6)? \\
\hline
\end{tabular}

\section{Outcomes and discussion}

As a result of expert evaluations, for the hierarchies presented in Fig. 1-3 we obtained the corresponding values of general consistency:

for the NE type - 0,048;

for TE - 0,044;

for the NA type - 0,047 ,

which indicates MHA correct application.

The analysis of the constructed hierarchies made it possible to establish that, in the presence of necessary and sufficient information, the BND forecasting during radiation monitoring can occur:

- NE identification by the TNE criterion with the following priority:
1 -TNE-3 (42,4\%); 2 - TNE-5 (24,9\%);

3 -TNE-4 (21,3\%); 4 -TNE-2 (7,7\%);

5 -TNE-1 $(3,7 \%)$;

- NE identification by the TNA criterion with the following priority:

1 -TNA-2 (36,6\%);

2 -TNA-3 $(29,9 \%)$;

3 - TNA-1 -1 $(33,5 \%)$;

- NE identification by the TE criterion with the following priority:

1 - TE-5 (38,6\%); 2 - TE-1 (24,6\%);

3 - TE-2 (15,2\%); 4 - TE-3 (12,4\%);

5 - TE-1 $(9,2 \%)$

- DF evaluation of the NE in the presence of information on the TNE: 
1 - DF-4 (50,3\%); 2 -DF-1 (15,15\%);

3 - PF-2 (14,85\%); 4 - PF-5 (11,5\%);

5 - PF-6 (4,85\%); 6 - PF-3 (3.35\%);

- DF evaluation of the $\mathrm{NE}$ in the presence of information on the TNA:

1 - DF-2 (34,22\%); 2 - DF-4 (22,45\%);

3 - DF-1 (19,75\%); 4 -DF-5 (10,5\%);

5 - DF-6 (9,3\%); 6 -DF-3 (3.8\%).

- DF evaluation of the NE in the presence of information on the TE:

1 - DF-2 (28\%); 2 - DF-6 (23,2\%);

3 - DF-4 (22,79\%); 4 - DF-3 (9,7\%);

5 - DF-5 (8.3\%); 6 -DF-1 (8\%);

- BND evaluation in the information presence on the TNE and on the DF of NE:

1 -BND-2 (43,1\%); 2 -BND-1 (37,3\%);

3 -BND-3 (14,4\%); 4 -BND-4 (5,2\%);

- BND evaluation in the information presence on the TNA and on the DF of NE:

1 - BND-2 (47,1\%); 2 - BND-1 (29,8\%);

3 - BND-3 (17,4\%); 4 - BND-4 (5,7\%);

- BND evaluation in the information presence on the $\mathrm{TE}$ and on the DF of NE:

1 - BND-2 (55,2\%); 2 - BND-1 (24,6\%);

3 - BND-3 (15,8\%); 4 -BND-4 (4,4\%).

The evaluation outcomes of the contribution of the NE initial «necessary and sufficient» parameters of different power, TNE and TNA make it possible, under the uncertainty of the initial information, to correctly assess the emergent situations in BND in the radiation monitoring framework of military emergencies.

\section{Conclusions}

1. The subcriteria variability importance for all hierarchies considered (see Fig. 1-3) indicates the priority of CV-3 (67,15\%), CV-1 (26,55\%), CV-2 $(6,3 \%)$. This fact points to the obvious need to take into account the neutron radiation spectrum in forecasting the nuclear damage boundaries. As sufficient additional information for making adequate and effective nuclear damage boundaries forecasting, it is advisable to adopt the neutron radiation spectrum of the nuclear explosion.

2. The analysis carried out by experts shows that for assessing nuclear damage boundaries on both the basis of the nuclear explosion type, the nuclear explosion power, and the nuclear ammunition type, the radiation-mechanical damage (BND-2) source with the criteria weight contributions will be better predicted and identified respectively: for the nuclear explosion type $(43,1 \%)$, for the trotyl equivalent $(55,2 \%)$, for the nuclear ammunition type $(47,1 \%)$.

3. From the point of view of identifying combined nuclear damage boundaries and radiation damage in the «pure» form, the criterion based on the nuclear ammunition type, respectively, for BND-3 $(17,4 \%)$ and for BND-4 (5,7\%) is the best. It is important to note that in assessing this situation, the power and height nuclear explosion specification could be considered necessary parameters, and the determination of the spectral characteristics of the neutron nuclear radiation is sufficient.

\section{REFERENCES}

1. Vasilenko, O.I. and Vasilenko, I.Y.,(2004), "Nuclear weapons of the new generation and its radiation-hygienic aspects", Atomic Energy Bulletin, No. 1, pp. 60-62.

2. Levshin, V.I, Nedelin, A.V. and Sosnovskiy, M.E. (1999), "On the use of nuclear weapons for the de-escalation of hostilities", Military thought, No. 3(5-6), pp. 34-37.

3. Belous, V. (1996), "Tactical weapons in new geopolitical conditions", Nuclear control, No. 14, pp. 2-7.

4. (1977), "Neutron weapons and the nature of its impact", Civil Defense, No. 6, pp. 98.

5. Sokov, N. (1997), "Tactical nuclear weapons: new geopolitical realities or old mistakes", Nuclear control, No.26, pp. 12-19.

6. Cherniavskiy, I.Y., Marushchenko, V.V. and Matykin, A.V. (2016), "Assessment of radiation injury by predicting dose loadings according to combat capability sensor", Systems of Arms and Military Equipment, Scientific and Technical Journal, Ivan Kozhedub Kharkiv National Air Force of Ukraine, No. 1(45), pp. 125-133.

7. Cherniavskiy, I.Y., Tyutyunik, V.V. and Kalugin, V.D. (2016), "Analysis of the conditions for the creation of a system for identifying and assessing the level of radiation safety of the vital activity of the population in emergency situations of a military nature", Collection of scientific works, Problems of emergency situations, National University of Civil Protection, No. 23, pp. $168-185$.

8. Cherniavskiy, I.Y. (2015), "Military dosimetry as system of identification and assessment of radiation situation", Science and Technology of Air Force of Ukraine, Scientific and Technical Journal, Ivan Kozhedub Kharkiv National Air Force of Ukraine, No. 4(21), pp. 126-133.

9. Kutsenko, S.A., Butomo, N.V. and Grebenyuk, A.N. (2004), Military toxicology, radiobiology and medical protection, Publishing House "Foliant", St. Petersburg, 528 p.

10. Khoruzhenko, A.F. (2014), "Combined radiation injuries in emergency situations of civil and military time", Civil Protection Strategy: Problems and Research, No. 1 (4), pp. 310-323.

11. Recommendations on the assessment of the consequences of the impact of the detrimental factors of a nuclear explosion on the personnel of troops, naval forces, civil defense formations and the population, Order N.310 of the Ministry of Defense of the USSR, 1983, $43 \mathrm{p}$.

12. (1977), Instruction on diagnostics, medical sorting and treatment of acute radiation damage, Ministry of Health of USSR, $29 \mathrm{p}$.

13. (2013), Clinical recommendations for the provision of medical care to victims of ionizing radiation in emergency situations, Ministry of Health of the Russian Federation, Moscow, $72 \mathrm{p}$.

14. Gozenbuk, V.L., Keirim-Marcus, I.B., Savinskiy, A.K. and Chernov, E.N. (1978), Dose load per person in fields of gammaneutron radiation, AtomPublishing, Moscow, $168 \mathrm{p}$.

15. Cherniavskiy, I.Y., Marushchenko, V.V., Gaydabuka, V.Y., Pisarev, S.A., Men'shov, S.N. and Matikin, V.B. (2016), "Biological aspects of impulse exposure of radiation factor which has military nature", Information Processing Systems: Scientific Works of National Air Force University, No. 5(142), pp. 193-201. 
16. Saaty, T. and Kerns, K. (1991), Analytical Planning. The Organization of Systems, Radio and communication, Moscow, $224 \mathrm{p}$.

17. Saaty, T. (1993), Making decisions. Method for analyzing hierarchies, Radio and communication, Moscow, $320 \mathrm{p}$.

18. Anishchenko, L.Y., Sverdlov, B.S. and Pisnya, L.A. (2009), "Choice of environmentally safe version of the ship's course on the basis of multi-criteria complex impact assessment using expert-analytical procedures", Collection of scientific works, Ukrainian Research Institute of Ecological Problems, pp. 38-60.

Received (Надійшла) 02.02.2018

Accepted for publication (Прийнята до друку) 30.05.2018

\title{
Експертно-аналітичне прогнозування осередків ядерного ураження у завданнях моніторингу надзвичайних ситуацій воснного характеру
}

\author{
Л. А. Пісня, І. Ю. Чернявський, С. Ю. Петрухін, О. М. Сєрікова
}

Актуальність. Розглянуто задачу комплексного оцінювання можливих осередків ядерного ураження у надзвичайних ситуаціях воєнного характеру. Метою роботи $є$ визначення «необхідних і достатніх» параметрів ядерного вибуху та оцінка ïx внеску в задачах ідентифікації осередків ядерного ураження, виявлення їх особливостей і меж, оцінки доз гамманейтронного опромінення населення та ефективного розподілу сил і засобів для дій в осередках ядерного ураження. Метод. 3 метою коректної оцінки ситуації в осередках ядерного ураження і планування необхідних заходів проведено оцінку внеску вихідних «необхідних і достатніх» параметрів виявлення ядерного вибуху різної потужності, виду та типу боєприпаса за критеріями вимірюваності із застосуванням метода аналізу ієрархій Т.Сааті, адаптованого для задач, що розглядаються. Перевагою застосування метода аналізу ієрархій для задач комплексного оцінювання можливих осередків ядерного ураження у надзвичайних ситуаціях воєнного характеру, є можливість знаходження вагових коефіцієнтів кожного елементу складної ієрархічної системи із урахуванням його взаємозв'язків та взаємовпливу шляхом попарних експертних порівнянь. Отримані вагові коефіцієнти (пріоритети) за рівнями ієрархії дозволяють визначити внесок елементів нижнього рівня на досягнення мети, яку сформульовано на верхньому рівні. Запропоновано процес оцінювання осередків ядерного ураження у вигляді трьох задач за критеріями по видах ядерного вибуху, тротиловому еквіваленту і типом боєприпаса, які являють собою комплексне експертно-аналітичне оцінювання уражаючих факторів ядерного вибуху. Результати. У роботі наводяться результати експертно-аналітичного оцінювання можливих осередків ядерного ураження у надзвичайних ситуаціях воєнного характеру в умовах невизначеності вихідної інформації при виявленні ядерних вибухів. Висновки. Підтверджено необхідність врахування спектра нейтронного випромінювання під час прогнозування осередків ядерного ураження в якості «достатньої» інформації з метою прийняття адекватних і ефективних прогнозів осередків ядерного ураження. Визначено, що під час проведення оцінки осередків ядерного ураження, як на основі виду ядерного вибуху, його потужності, так і типу ядерного боєприпаса найкраще буде прогнозуватися та виявлятися (ідентифікуватися) осередок радіаційно-механічного ураження. Під час виявлення комбінованого радіаційного ураження і радіаційного ураження в «чистому» вигляді найкращим $є$ критерій на основі типу ядерного боєприпаса.

Ключові слова: осередок ядерного ураження; уражаючі фактори ядерного вибуху; метод аналізу ієрархій; експертно-аналітична оцінка.

\section{Экспертно-аналитическое прогнозирование очагов ядерного поражения в задачах мониторинга чрезвычайных ситуаций военного характера}

\section{Л. А. Писня, И. Ю. Чернявский, С. Ю. Петрухин, Е. Н. Серикова}

Актуальность. Рассмотрена задача комплексной оценки возможных очагов ядерного поражения в чрезвычайных ситуациях военного характера. Целью работы является определение «необходимых и достаточных» параметров ядерного взрыва и оценка их вклада в задачах идентификации очагов ядерного поражения, выявление их особенностей и границ, оценки доз гамма-нейтронного облучения населения и эффективного распределения сил и средств для действий в очагах ядерного поражения. Метод. С целью корректной оценки ситуации в очагах ядерного поражения и планирования необходимых мер проведена оценка вклада исходных «необходимых и достаточных» параметров обнаружения ядерного взрыва различной мощности, вида и типа боеприпаса по критериям измеряемости с применением метода анализа иерархий Т.Саати, адаптированного для рассматриваемых задач. Преимуществом применения метода анализа иерархий для задач комплексной оценки возможных очагов ядерного поражения в чрезвычайных ситуациях военного характера, является возможность нахождения весовых коэффициентов каждого элемента сложной иерархической системы с учетом их взаимосвязей и взаимовлияния путем попарных экспертных сравнений. Полученные весовые коэффициенты (приоритеты) по уровням иерархии позволяют определить вклад элементов нижнего уровня на достижение цели, которая сформулирована на верхнем уровне. Предложено процесс оценивания очагов ядерного поражения в виде трех задач по критериям: виду ядерного взрыва, тротиловому эквиваленту и типу боеприпаса, которые представляют собой комплексное экспертно-аналитическое оценивание поражающих факторов ядерного взрыва. Результаты. В работе приводятся результаты экспертно-аналитического оценивания возможных очагов ядерного поражения в чрезвычайных ситуациях военного характера в условиях неопределенности исходной информации при выявлении ядерных взрывов. Выводы. Подтверждена необходимость учета спектра нейтронного излучения при прогнозировании очагов ядерного поражения в качестве «достаточной» информации с целью принятия адекватных и эффективных прогнозов очагов ядерного поражения. Определено, что при проведении оценки очагов ядерного поражения, как на основе вида ядерного взрыва, его мощности, так и типа ядерного боеприпаса лучше будет прогнозироваться и проявляться (идентифицироваться) очаг радиационно-механического поражения. При обнаружении комбинированного радиационного поражения и радиационного поражения в «чистом» виде лучшим является критерий на основе типа ядерного боеприпаса.

Ключевые слов а: очаг ядерного поражения; поражающие факторы ядерного взрыва; метод анализа иерархий; экспертно-аналитическая оценка. 